\title{
Song Texts in Music for Entertainment
}

This chapter will examine some song texts performed in music for entertainment that I recorded in 1976, 1992 and 2003, and that are presented in Appendix 4. A few of these texts were published in Van Zanten (1995), some with the transcription of the sung melody. A performed text is not necessarily a text 'as it should be' according to theory, and I will pay attention to the performing aspects of the texts that I recorded. Section 7.1 discusses earlier publications of song texts, in particular as presented by Van Hoëvell (1845), Meijer (189o) and Pleyte (1912). In Appendix 4 you may find some remarks about methodological issues concerning the collection of my texts.

The texts are in the form of 4-line susualan or sisindiran that are called pantun elsewhere in Indonesia and not to be confused with the Sundanese pantun stories discussed in Chapter 6. Section 7.2 will treat formal aspects of the texts and Section 7.3 will discuss themes in the song texts performed by the female singer Raidah in March 2003. Section 7.4 will conclude this chapter with a discussion of major themes in the other susualan in Appendix 4.

A particular melody (song) may be used with different texts, and the performers may make new, or partially new, texts. Also a particular susualan text may be sung with different accompaniment (angklung, zither + violin, etc.). For instance, I recorded the song Kembang Beureum (Red Flower) with keromong accompaniment and also with the combination of kacapi and rendo accompaniment. Moreover, the song was also played instrumentally: I recorded Kembang Beureum played by solo instruments rendo (1976), suling lamus $(1976,1992)$ and kacapi siter (2003). The Inner Baduy Karamaén from Cibéo told me that there is no difference in the use of the voice when singing susualan (wawangsalan) or pantun stories, as I had suggested in my 1995 article (A2003-2: 6; Van Zanten 1995: 530-531).

\section{Earlier Publications of Song Texts}

Probably the earliest publication of Baduy sung texts was by Van Hoëvell (1845: 411-427), who presented the verses that he 'with the help of the Lebak regent wrote down after hearing it from their mouth'. He called these verses panton and presented the Sundanese texts with a Dutch (annotated) translation. On page 427 Van Hoëvell warns that for the greater part these verses 
may also be found in the other Sundanese regions, 'even in the Priangan and Cirebon'. Sometimes literally, and sometimes a few words are slightly different. Anyway, we should be aware that only a few of his presented texts are unique for the Baduy community, he wrote.

Van Hoëvell also supplied evidence of the musical exchange between the Baduy and the outside world. On p. 421 he commented in footnote 2 that these verses are sung in the evening with angklung and that on such occasions there are many in the audience who come from outside the hamlet ('kampong'). Although it is not exactly clear what he means by the Baduy 'kampong' and who these outsiders are, it shows that there were no attempts to keep these verses hidden for outsiders, as happens with ritual music.

Moreover, in the 19th century several authors reported that Baduy groups also play their music outside Kanékés. Van Hoëvell (1845: 428-429) mentions the suling flute (presumably suling lamus), the two-string bowed lute rendo and the kacapi plucked zither that accompany singing by 'two boys of twelve or fourteen years old'. Those groups play for entertainment in Kanékés, but also outside Kanékés: 'Often such a group of five instrumentalists and singers descends from the Baduy mountains into the plains of Lebak to perform their melodies during feasts and solemn happenings: but then they always are Outer Baduy; the Inner Baduy do not leave their hamlet'.

Meijer (189o: 471) was critical about Van Hoëvell's work. He commented that Baduy do not know susualan and that Van Hoëvell was wrong in stating that (some of) the published verses came from the Baduy. According to Meijer (1890: 475-6), the susualan in South Banten correspond with 'the Malay pantun in Batavia, and these texts are part of the repertoire of the comedian (ogel), and street musicians who accompany themselves on an angklung set (pangangklung), a bamboo xylophone (calung), or drums (doblang, bedug). The performer tries to get the audience laughing and 'The villagers listen with pleasure to their sisindiran, but these are mostly not fit for European ears. He sees no objection at all to express himself as crudely as possible. Nevertheless, Jai, Jasma, Sarilah and Saripah [women's names] happily listen to his very daring wits and without bashfully casting down their eyes now and then'. In his 1890 article Meijer only presented the 'innocent' (onschuldige) stanzas that he found in South Banten and left out the ones that he considered too crude (Meijer 189o: 476-477).

In Section 3.3 and especially the part 'Criticism by Jacobs and Meijer (1891) and Pennings (1902)' I already commented that I find Meijer's criticism on Van Hoëvell not entirely justified. In the light of my own recordings and research by others, it seems highly improbable that in the 19th century 'they [Baduy] do not know such poetry' as published by Van Hoëvell in 1845 (Meijer 189o: 471.). 
Baduy know about temptations, including the sexual ones, and the musical setting is suitable for performing these susualan, sometimes with 'daring wits'. Susualan, like most Indonesian poetry, should not be read in a book, but performed. Apparently this is a safe way to 'discuss' erotic feelings and sexual issues in their communities. When I asked information about song titles or song texts, often the explanation was given with some shy smiling. In 2003 the Inner Baduy Karamaén from Cibéo said that the 'atmosphere' (intonasi) for singing susualan (wawangsalan, bangbalikan) is called ngabojégan: poking fun, making jokes. On 5 June 2014 Karamaén played three instrumental tarawélét pieces that I recorded on audio and video. The songs were called 'To drop in at the widow' (Noong Rangda), 'To sway one's arms when happy' (Keupat Reundang) and 'The widow throws her arms around him' (Rangda Ngeukeupan). Karamaén and his companion, a smith from Cibéo, were laughing and clearly amused when mentioning and explaining these song titles to me and my assistant Mumu (film 2014-2, 32', 34', 38').

Twenty-two years after Meijer, Pleyte (1912) published his long article 'Baduy Brainchildren' (Badoejsche Geesteskinderen) that we already mentioned as one of the important sources for the Baduy pantun stories. This article also contains susualan texts with a Dutch translation and introductory notes. Pleyte (1912: 254) contradicted Meijer by mentioning that at Baduy gatherings there 'may be much fun, as in other parts of Sunda', as the rising Baduy generation is also very capable of playing word games (bangbalikan, a special form of susualan: see below). The evening parties where the youngsters meet and alternatingly sing to each other, must have been very cheerful. Pleyte (1912: 255) called these meetings during the evening, in which ten to twelve unmarried boys take place, each with their kacapi: ngaroronda. On such occasions they sing about love ('Eros waart alsdan bovenal rond ...') and Pleyte presented examples of susualan. According to him the Baduy were equally passionate and the men equally charmed by the 'eternal female' (das ewig weibliche) as other human beings (Pleyte 1912: 256-257). From Pleyte's report it is not clear whether women also sang the susualan at that time, as they do nowadays.

I leave a thorough discussion of the contents of the stanzas (susualan) published by Van Hoëvell (1845), Meijer (189o) and Pleyte (1912) to others. However, on first sight I find it striking that only very few lines in these earlier publications are also found in the susualan that I collected (Appendix 4). This may be an indication that there is much improvisation of the texts and little standardization. This contrasts with some parts of the texts in pantun stories, like the introduction (rajah), as discussed in Chapter 6 above, that seem to have core elements that were the same over at least about one hundred years. 
Before discussing the contents of the texts that I recorded myself, Section 7.2 will discuss a few issues about the formal structure of the texts.

\subsection{Formal Aspects of the Song Texts}

Baduy song texts in music for entertainment are mostly presented in susualan (or sisindiran) form. A susualan is 'an allusion, consisting of a combination of words that suggests the real meaning by sound association and the like' (Eringa 1984: 718). Most susualan in Appendix 4 consist of 4-line verses in which the first two lines are the 'rind', 'skin' or 'cover' (cangkang) 'without meaning', followed by the last two lines with the 'content' or 'essence' (eusi), the real meaning. The last syllables of the first and third lines are in rhyme and this also holds for the second and fourth lines. An example is given in verse 3 of the song Kacang Asin, sung by the female singer Raidah on 26 March 2003:

Ari kacang kacang asin

Asinna dibeungkeutan

Abdi isin abdi isin

Isinna ku dideukeutan
Peanuts, salted peanuts

The salt is put to it

I am ashamed, I am ashamed

The shame is because we were close together

This example also shows that most lines consist of eight syllables, which is one of the characteristics of the classical Sundanese verse form (purwakanti; see Van Zanten 1989: 65-66); only line 2 has seven syllables. In fact, in a musical performance this preferred length of eight syllables per line is often broken and words are repeated and/or stopgaps added. The performed text of line 4 consisted of 12 syllables, 'Isinna mah, isinna ku dideukeutan': 'The shame, the shame is because we were close together' (see Appendix 4).

Another example is stanza 7 of the performed text of '2003-04Jalan' in Appendix 4 , in which the musical performance $<\mathrm{AV}_{1} 8>$ includes repetition and addition of text:

Kanikir mah kanikir

Jeung kembang gambir

Kanikir jeung kembang gambir

Jungjunan, tangkal honjé jeung kanyéré

Dipikir beki kapikir

Horéng mantak $(2 \mathrm{x})$ rajét haté
The kanikir plant

And the gambir flower

Kanikir and gambir flower

My lord, the honjé and kanyéré trees

I am worrying all the time

This causes my heart to break 
If we take away the words of the first two lines that are later repeated, the word 'Jungjunan' in the fourth line and the repeat of 'horéng mantak' in the 6th line, we obtain the 'pure' susualan form, the theoretical form with four lines of 8 syllables each:

Kanikir jeung kembang gambir Tangkal honjé jeung kanyéré Dipikir beki kapikir Horéng mantak rajét haté

\author{
Kanikir and gambir flower \\ The honjé and kanyéré trees \\ I am worrying all the time \\ This causes my heart to break
}

If the sound patterns of lines $1-2$ and lines $3-4$ are parallel the susualan is termed a paparikan. This is - to some extent - the case in the above example. A wawangsalan or bangbalikan is a susualan in which the first two lines paraphrases some word not mentioned in the text. See examples and more details on performed susualan (sisindiran) for instance Van Zanten (1989: 68-70). Pleyte (1912: 257-259) presents a few susualan of which both the 'rind' and the 'content' consist of 3, 6 or 7 lines. Not all the different forms of susualan will be treated in this chapter, but rather the content and some performance aspects. However, before that I would like to make a short remark about the macapat verse forms that seem to be fairly common around Kanékés, but not used by the Baduy.

Macapat verse forms, originating from central Java, have been used for Islamic teachings since Islam entered west Java. We still find the reading and reciting of exemplary deeds of Islamic saints (manikaban) in west Java, including South Banten. Referring to Julian Millie's work, I wrote (Van Zanten 2011: 250) that these gatherings are meant 'to seek divine favor (barokah) from Allah through the intercession of Sheikh Abdulqadir al-Jaelani (471-561, 1077/ 78-1166 CE), a saint whose tomb has become a place of veneration in Baghdad (Millie 2003: 1, see also Millie 2006)'. Millie (2003: 2) also mentioned that '[T] he custom of manikaban is widespread and growing at the present time [...] and most frequently performed in the homes of the followers of the sufi order known as the Tarik Qadiriyah wa Naqshabandiyah ...' Meijer (1890: 470) already mentioned that this custom was practised in South Banten. This was confirmed on 21 July 1976 when I recorded a non-Baduy, Pak Oyo from the dangka hamlet Cihandam, just north of Kanékés (see Figure 13 in Section 2.2). He sang solo songs in macapat verse forms that Julian Millie later identified as manikaban.

Again, the Baduy do not use the macapat verse forms, but only the classical purwakanti and the susualan forms. The susualan may be sung with accompaniment of keromong, angklung, kacapi and suling, and kacapi and rendo. 
The same text may be sung with different accompaniment, also a stanza may be sung twice in the same song. Section $7 \cdot 3$ below will discuss the susualan texts as performed by the female singer Raidah and her companions in March 2003 in Kaduketug 1. Section 7.4 will comment on the other texts presented in Appendix 4.

\subsection{Song Texts Used in Performance by Female Singer Raidah in 2003}

The collected song texts in Appendix 4 are possibly biased. It may be that, for instance by self-censorship of the musicians, I obtained 'innocent' verses and that I did not hear the most 'crude' ones: words that Meijer (1890: 477) used for describing the texts that he did or did not include in his publication. However, all ethnographic data have a bias, and the given texts are only one way of looking at the Baduy community. This chapter discusses the recorded texts in connection with some performative aspects: the musical context in which the texts are presented. The presented analysis will be relatively simple. However, the Baduy song texts and the performative aspects deserve a more comprehensive analysis.

Most song texts for entertainment presented in Appendix 4 are about love, sometimes erotic and/or expressing sexual longing for someone, sometimes exposing frictions between husband and wife and a separation. The past is another theme in some of the songs, and others include advice on how to live properly. And, indeed, some texts are a little blunt or crude as Meijer said, but most texts allude to matters in a veiled form: they are susualan with some layers of meaning.

The discussion of the content and some performance aspects of the susualan will start by looking at the performance by the female singer Raidah on the evening of 26 March 2003. She was accompanied on violin (viol) by her husband Arip and on a flat kacapi siter by Satra (Satrawinata); see Figure 49. In the last three songs a male singer, Salim, sang a few verses in alternation with Raidah (Figure 50). This evening took place at the end of the Baduy month Kasa, the first of the three fasting months (kawalu). I had asked for this performance at the house of the secular village head Daénah, because I recorded Raidah (earlier written as Raida) also in 1992 and I knew she was a well-known performer; see also Van Zanten (1995:531-532). My assistant Mumu transcribed the texts from the recordings and these were checked with others, including the zither player Satra. Then we discussed the notated song texts with Raidah, Arib and Mumu a few days after the recordings. See further the methodological remarks in Appendix 4. 
Between about 20.15 and 22.50 Raidah, Arib and Satra played eleven songs, altogether with about seventy susualan. In between the songs, there were discussions, people smoked and drank coffee or tea. Now and then people in the audience reacted to the words sung by Raidah. In the last three songs of this evening, starting from 2003-09 Kapergok, the young man Salim sang a few stanzas. He 'answered' the text sung by Raidah before. This type of singing by a man who is 'breaking into' the performance by a female singer is common in Sunda and called alok. I will now discuss the song texts performed that night and follow the order in which they were sung. The first song was Kidung Rahayu.

\section{7·3.1 Kidung Rahayu}

In 1995 I wrote that '[T] he Baduy do not use kidung in the Sundanese sense of 'singing' an incantation to avert illness, theft, and possible evils when entering places that might harbour spirits' (Van Zanten 1995: 529; compare Van Zanten 1989: 17-18). However, this text of the song Kidung Rahayu, recorded in 2003 at the start of the performance and recording session, apparently denies this.

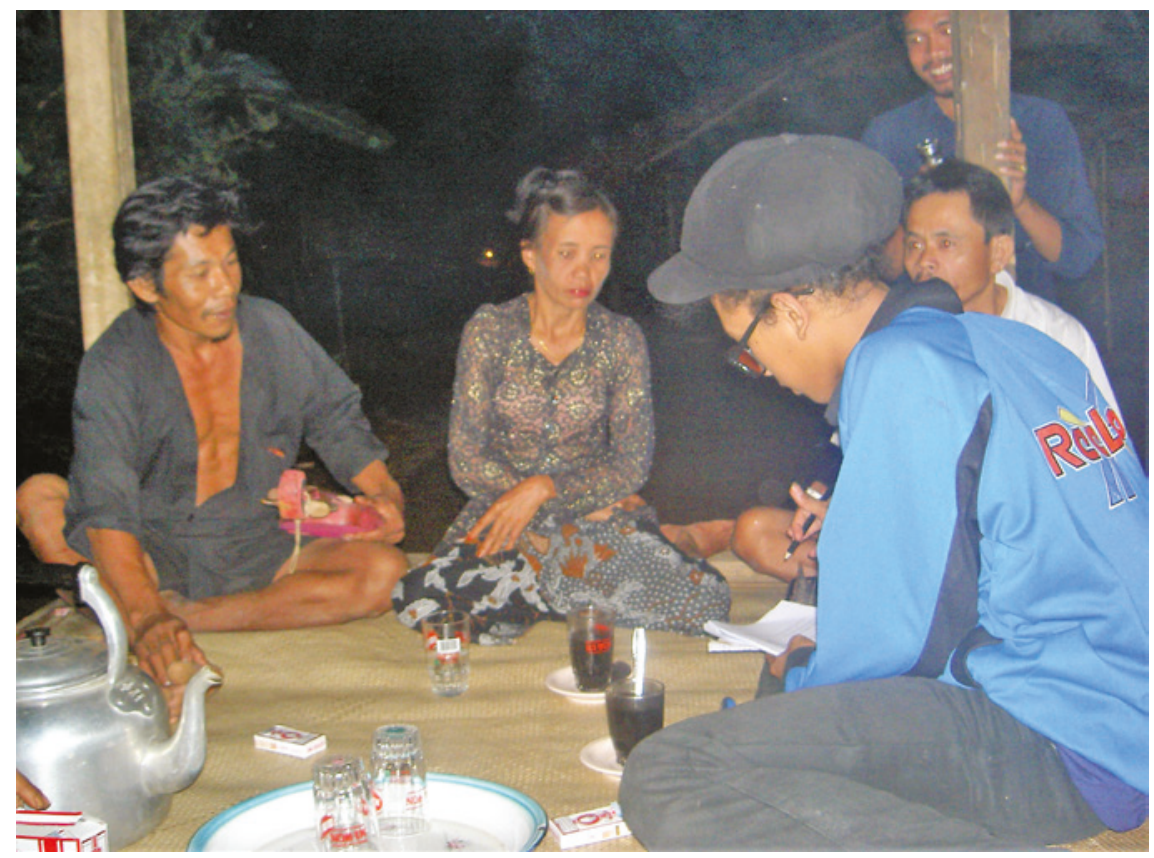

FIGURE 49 From L to R violin player Arib, his wife and female vocalist Raidah and the zither player Satra, interviewed by Mumu during their performance in Kaduketug, 26 March 2003 
Here it seemed to be used as an incantation to avert evil influences and to supply holy prosperity: 'In the name of God ...' and 'burning incense rises into the air ...' In stanza 4 Raidah sings about the 'wind of prosperity' (bayu rahayu) and 'wind of love' (bayu asih) that are living 'in the present world'.

The text further reminds the audience that they are the descendants ('children') of the famous Siliwangi, king of the Hindu kingdom Pajajaran (14-16th century CE), who had his seat near the present-day Bogor. This seems not entirely in line with the current 'official' Baduy view as presented in the beginning of Chapter 3: a strong denial that they are descendants of people who fled Pajajaran when the Islamic forces took over in 1579. It may be that this song text came from outside the Baduy community, because in general the Sundanese consider themselves to be the 'children of Siliwangi'. This Kidung Rahayu text finishes with: 'we respectfully give you all this, we present it, although we are ignorant, I and my friends'.

The beginning (rajah) of a pantun story contains similar elements as this Kidung Rahayu text; see Section 6.5 above. I do not know how common such Kidung Rahayu text is. It may be that the time of this recording, in one of the fasting months of kawalu, had some influence on this opening text. During the circumcision rituals that I attended in Kadujangkung and Cicakal Leuwi Buleud in 2016, the keromong regularly played Kidung Rahayu and also Kidung Opat-Lima (see Sections 4.4 and 4.5). Unfortunately I was then not allowed to record the activities and I was not able to obtain the text of these songs. Also, at that time Kidung Rahayu and Kidung Opat-Lima were not played at the start, but in between other songs. Further, the song Kidung is not only played by gamelan with vocal part, but also instrumentally by the elét and suling lamus.

\subsubsection{Tepang Sono}

The second song was Tepang Sono (Affectionate Meeting) and it also shows some aspects of an 'opening'. Raidah addresses the 'Highly honoured one(s)' (jungjunan) for whom she is going to perform 'the Sundanese arts from previous generations, the heritage from our ancestors'. She hopes that she will not fail in bringing the right feeling of affection across. If the musicians fail, make mistakes, she apologizes.

\subsubsection{Daun Hiris}

The third song was Daun Hiris, (Leaves of the hiris shrub) that can be found in Kanékés and the legumes are eaten by the Baduy. This is the first song of that evening that is about a love relation. A woman complains that her lover (husband?) no longer seems to care about her. She addresses him as 'panutan': the person to follow because you love him. Whatever she does to get him back, he 
has turned away from her: there are many temptations. She talks about the beautiful hiris leaves with its yellow flowers that we may see near the fishpond. But in the next stanza the singer confesses that she is jealous of the hiris leaves at the edge of the ravine, seemingly comparing the dangerous position of that plant with her own unavoidable fate. She is using nature as a metaphor for her human feelings, as is common in Sundanese songs.

\subsubsection{Jalan}

The main theme of this song 'The road/to travel' is again a broken love relation. The singer expresses despair: 'my thinking is chaotic, sad memories fill my mind', 'I am worried about the angry person, how shall I face him?', 'my friend has become a stranger' and 'my heart is weeping'. However, the performer also gives advice: 'do not desire that woman, she will make you ill because of thinking about her', 'you can help each other, in case of a mistake, forgive each other' and 'when a person is patient, surely he/she will become prosperous'.

It occurred twice in this song that the performer praised important people in the audience: the secular village head (Apa lurah, who had a 'nice character') and also the village secretary (Pa Haji Sapin, whom we like). The performance took place on the veranda of the house of the village head Daénah and he attended the whole evening. Also the village secretary (carik) Sapin was present during this performance. Sapin was born in Kanékés, but his family migrated in 1978, and he became a Muslim and made a pilgrimage to Mecca, hence the polite way of addressing him was 'Mr. Haji Sapin'.

\subsubsection{Gunjaér Mundur}

The song 'The gunjaér fish retreats' again offers a metaphor in nature by looking at the fish that retreats to the village square (stanza 1) and a small canal (stanza 2). The performer asks us (her lover?) not yet 'to go home', to retreat, because she wants to wait. Apparently she is still in doubt about the possibility of a good relation with her lover. This song expresses longing for a love relation without difficulties and anxiety that it may turn out badly: 'I am worried, I am thinking about and longing for you, it would be nice if you came to me', followed by 'How shall I become quiet, sir? Let it not disappear within a month' and 'where do I ask for help? My heart is so disturbed!' One stanza text offers wisdom: 'Sorrow and sweetness, sir, will go together'. Stanza 9 of this song is exactly the same as the performed stanza 8 of the previous song Jalan.

\subsubsection{Kacang Asin}

The text of this song 'Salted peanuts' is fairly simple and repeated in the susualan 1-3: 'I am ashamed, the shame concerns the two of us' and 'the shame is 
because we were close together'. Further Raidah repeated stanzas from earlier songs and with little variation: Jalan (stanzas 10, 4 and 1), Gunjaér Mundur (stanzas 10 and 6), Kacang Asin (stanzas 1 and 3). The 4th stanza is a special one. This susualan occurs a few times in my collection with some variation. The word kaniaya means 'injustice', 'cruel', 'oppressed', 'maltreated', or 'to punish' (Eringa 1984, KUBS 1976). I suppose that in this context it means illtreatment of a woman by her lover.

\subsubsection{Bayu-Bayu}

The song 'Vitality' or 'Breath of Life' is not about love, but rather a memento mori: your life is short and remember that one day you will die. In the $3^{\text {rd }}$ susualan it says: 'Life is governed by death, death's time is not known; that also holds for me, there is a return to the origin'. We 'live in this world as strangers' and we should not be jealous or greedy. We should not live like animals, but praise god, live like ascetics. Baduy believe that after death their spirit will return to where it came from: Sasaka Parahiang near Cibéo (see also Section 2.1).

\subsubsection{Poho Kabalik}

This song 'Forgetting to go home' starts by saying that 'we are enjoying happiness, like the happy people who forget to go home'. The second stanza is more serious: 'Although she does not live licentiously, elder brother, your wife is slandered; I am shaking, overcome with troubles'. Further, this song text warns: 'do not get distracted, otherwise it will cause confusion' and 'let not a charm of love be cast on you'. The singer also warns for the many good female singers: 'it feels as if you are put to sleep, especially when it is enjoyable'. Then 'the tiredness is not felt, work forgotten, no worrying about being rattled by fatigue'. However, these many distractions are no better than your wife who is waiting for you.

\subsubsection{Kapergok}

In this song 'Caught red-handed' and the following two songs Raidah's singing was alternating with a male singer Salim. This type of musical dialogue between a female singer and an alok singing man is much appreciated by the audience, and sometimes the singers are very inventive when improvising on susualan texts. I estimate Salim was at that time in his early twenties and I think he came from Kaduketug (see Figure 50).

In this musical dialogue the female singer started off: 'Hey (elder) brother, what are you doing? We happen to meet as if we are a couple in love'. The male singer denies this: he was not attracted to her when they met the other day. He 
then was just dreaming that he would be a rich man. She should not think that they were a couple in love, because 'it will increase your jealousy'. The female singer answers that she does not want to become a couple, because 'there is already proof that you have a girlfriend'. She accuses the boy of often switching and 'people watch this critically!' Then the boy reveals that he apparently hoped to have a chance with this girl: 'don't be rude [...] you dare to become angry at me, as if inviting [us] to split up'. The girl states again that she does not want to become a couple, because he already 'shares his heart' with someone else. After this the two singers repeated a few earlier susualan, sometimes with some variation.

After the start of Kapergok and singing the first susualan (stanza o in Appendix 4), the musicians started again and repeated this stanza (stanza 1 in Appendix 4). This time, after the first sentence of the female singer ('Hey, brother, what are you doing?'), the village secretary shouted: 'I am drinking coffee!' This type of interaction increases the happy atmosphere of the performance. The recording of susualan 1-3 of Kapergok may be heard in the audio-visual example $<\operatorname{AV} 19>$.

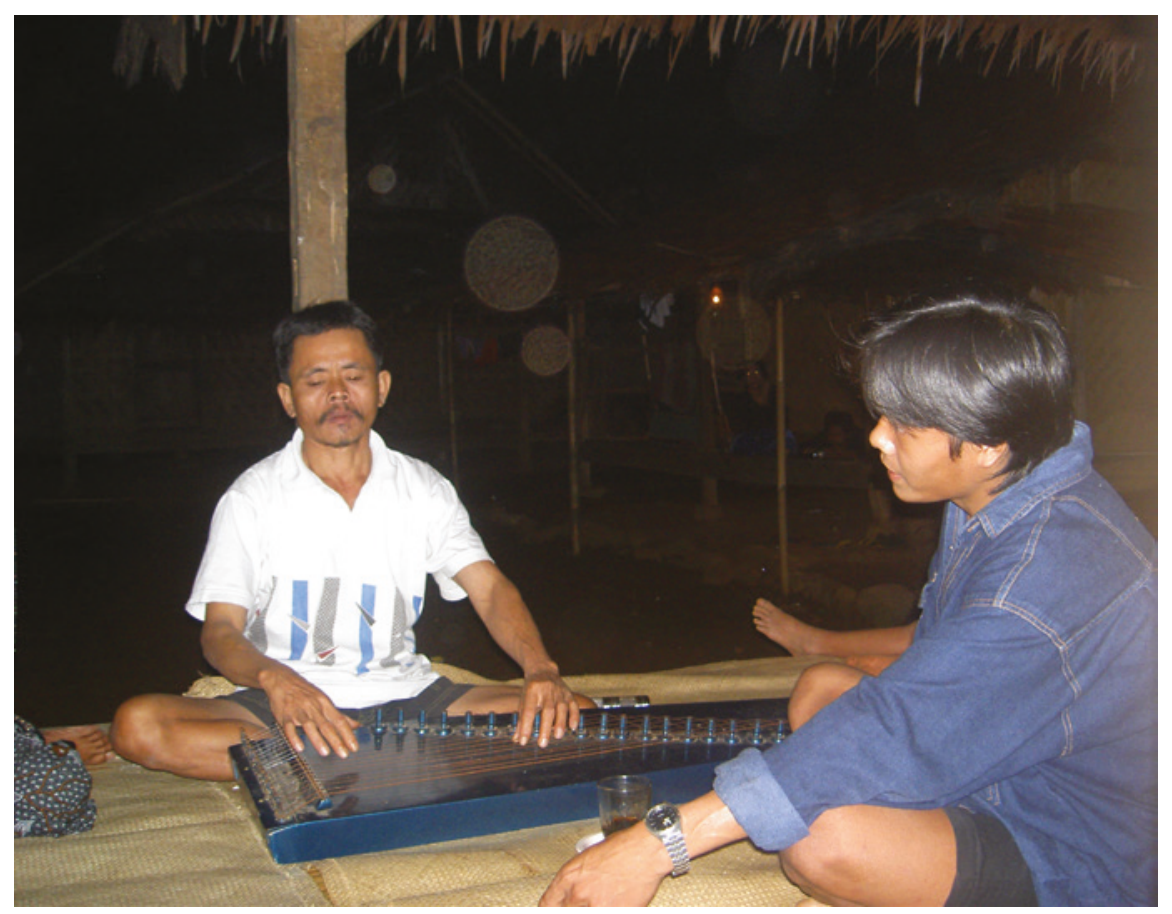

FIGURE 50 On the right Salim, who 'broke in' at Raidah's performance with alok singing; on the left is Satra playing the kacapi siter. Kaduketug 1, 26 March 2003 


\section{Kapergok}

Verses 1-3 sung by Raidah from Balimbing and Salim from Kaduketug, 2003

Recorded in Kaduketug on MD 2003-09, 39:53-41:10, 26 March 2003

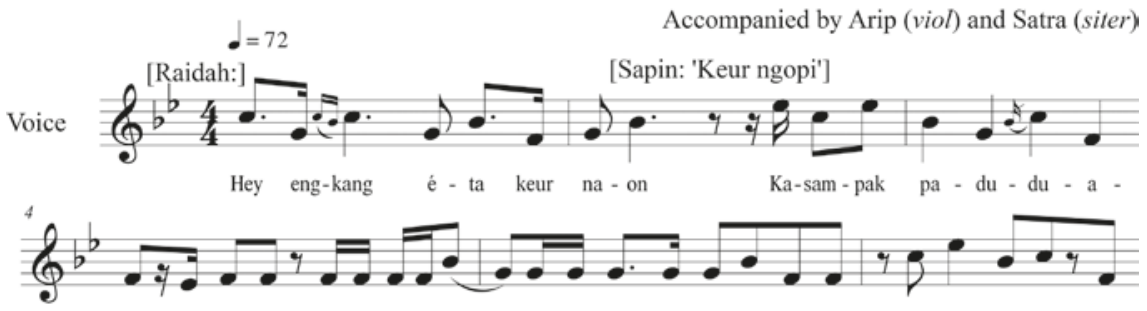

an Ka-sam-pak pa-du-du-a-an__ Sing ho-réng keur bo-bo-goh-an Sing ho-réng mah keur
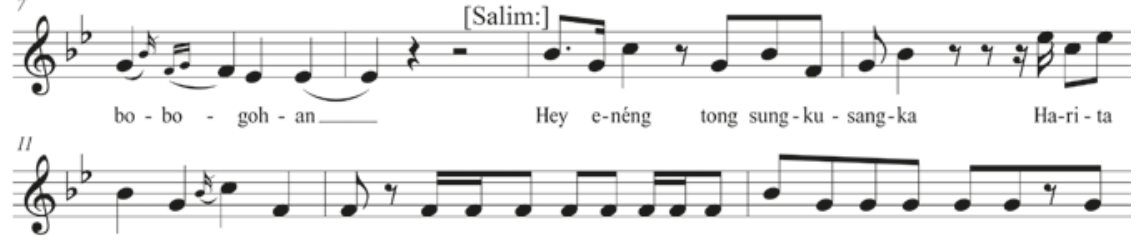

téh keur nga - la - mun Ha-yang mah ja - di je-le-ma beung-har U-lah nyang-ka sam -
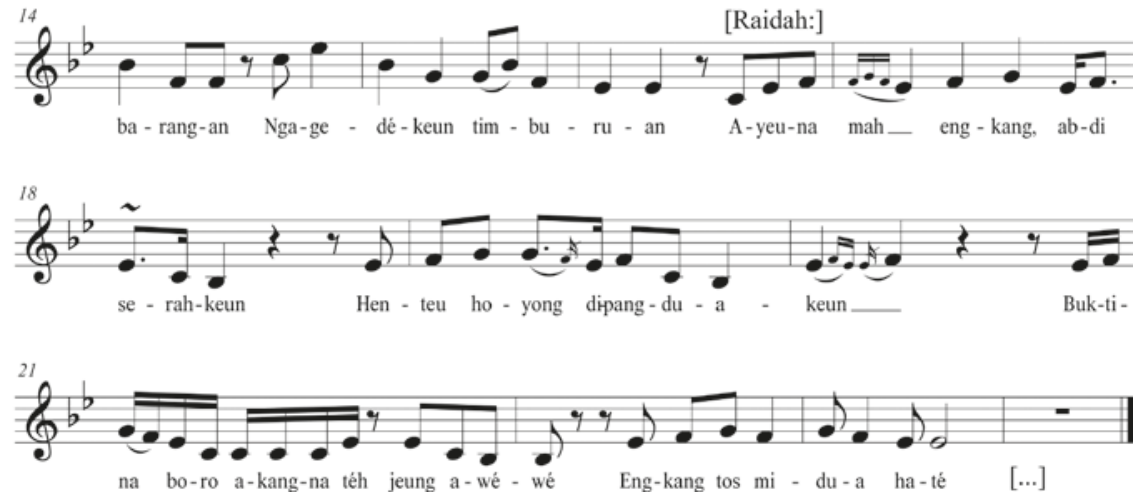

MUSIC TRANSCRIPTION TR 7 Susualan 1, 2, and 3 of song Kapergok, as sung by Raidah and Salim in Kaduketug, 26 March 2003. Listen to <AV19>

Music Transcription Tr 7 presents a part of the musical dialogue between Raidah and Salim in the song Kapergok. In the transcribed susualan 1, 2, and 3 , Raidah sang the first and third stanza and Salim the one in between. The used saléndro tone system is represented by the notes $\mathrm{c}-\mathrm{e}-\mathrm{flat}-\mathrm{f}-\mathrm{g}-\mathrm{b}-\mathrm{flat}-[\mathrm{c}]$ and this more or less represents the real pitches (with standard $a^{1}$ equal to $440 \mathrm{~Hz}$ ).

In his susualan Salim (bars 9-16) repeated the melody sung by Raidah before (bars 1-8), with a few variations, partly because he had to adjust for more or less syllables. In the following susualan (bars 16-23) Raidah introduced a new melody that was not repeated by Salim. Instead, the transcribed music in 
$\operatorname{Tr} 7$ is repeated three more times, with slight variation. That is, the susualan of Kapergok are sung to two different melodies. Hence in stanza's 1, 4, 7 and 10 the melody is the same and sung by Raidah. In stanza's 2, 5, 8 and 11 the melodies are also the same as in stanza's 1, 4, 7 and 11, but sung by Salim. Stanza's 3, 6, 9 and 12 are also sung on the same melody, however, this melody is different from the one used for the other stanza's. The melodic line lies in a lower pitch range than the first one. These stanzas were again all sung by Raidah.

My music transcription suggests that Raidah used more musical embellishments (grace notes, mordents and pitch vibrato) ${ }^{1}$ than Salim. However, on the whole, the emphasis seems to lie on the correct rendering of the partially improvised song text, rather than on the melodies and embellishments. The tempo indication of 72 beats per minute is only an average.

\subsubsection{Daun Puspa}

In this song 'Puspa Leaves' there were no jokes about a love relation as in the former one. The song seems to evoke a feeling of intimacy and the main issue is the sweetness of love: 'my dearest love, we were carried away by the wind of affection'. Nature around the couple was witness of these sweet memories of the lovers: the leaves of the tall puspa tree and also the nicely blinking stars. The female singer started by reminding her lover about his words that their love would not disappear in future, in contrast to the puspa leaves that wither and become dry. 'Your keen eye seduced my heart; when we separate it will cause a lingering illness'. Then the male singer confirms in a susualan that the puspa leaves have been witness from the start, when they expressed their wish to live together and love each other. Now these puspa leaves are falling and still witnessing their love. Raidah then finished by repeating the first two stanzas that she had sung before.

\subsubsection{Ucing-Ucingan}

This song 'Children's games' was the last one of the performance that evening. The title Ucing-Ucingan also refers to the word ucing, cat. In the 'cover' or 'rind' (cangkang) of most susualan of this song is mentioned that the 'spotted cat' has five, three, or two hairs, it has a tail, a multi-coloured skin or hair like the hiris shrub. The lines with the content (eusi) of the susualan do not always show a very clear meaning. The first line of the 'content', that is, third line of the susualan stanza, is invariably taken to be 'often I want to play' (sok hayang

1 Compare, for instance, Van Zanten (1989:163) for embellishments in Cianjuran music in the Priangan. 
ulin-ulinan) by Raidah. Presumably the 'playing' (ulin) also alludes to erotic playing (compare also Van Hoëvell 1845: 418, 421-422). Only stanza 5 and 10, sung by Salim, are different in this respect. A line with fairly clear meaning is 'When I am worried, I want to take [the cat] along' (stanza 7). In this context the 'cat' is a metaphor for 'girl'. In the last stanza (number 10), Salim sings that he hopes his friend will become his partner and that he may use medicine (obat) to make the process go smoothly.

So far the discussion of the song texts in the performance by Raidah and her companions in 2003, who could be considered to be 'professionals' in the Baduy community. After the performance people who had attended went home. I paid Arip as representative of the group (Rp 100.000, about $€$ 10, Us\$ 11). In the beginning of the concert we had stopped to get the transcription of the sung texts down on paper (see Figure 49). However, as this took much time and was not very interesting for the audience (see Figure 51), we then left this checking for later. Eventually Mumu and I discussed the transcribed texts with Raidah three days later, on Saturday night 29 March 2003, 20-22.35. For this session on the checking of the notated texts I paid Arip Rp 5 o.00o (about $€$ 5, US \$ 5.5) for the group.

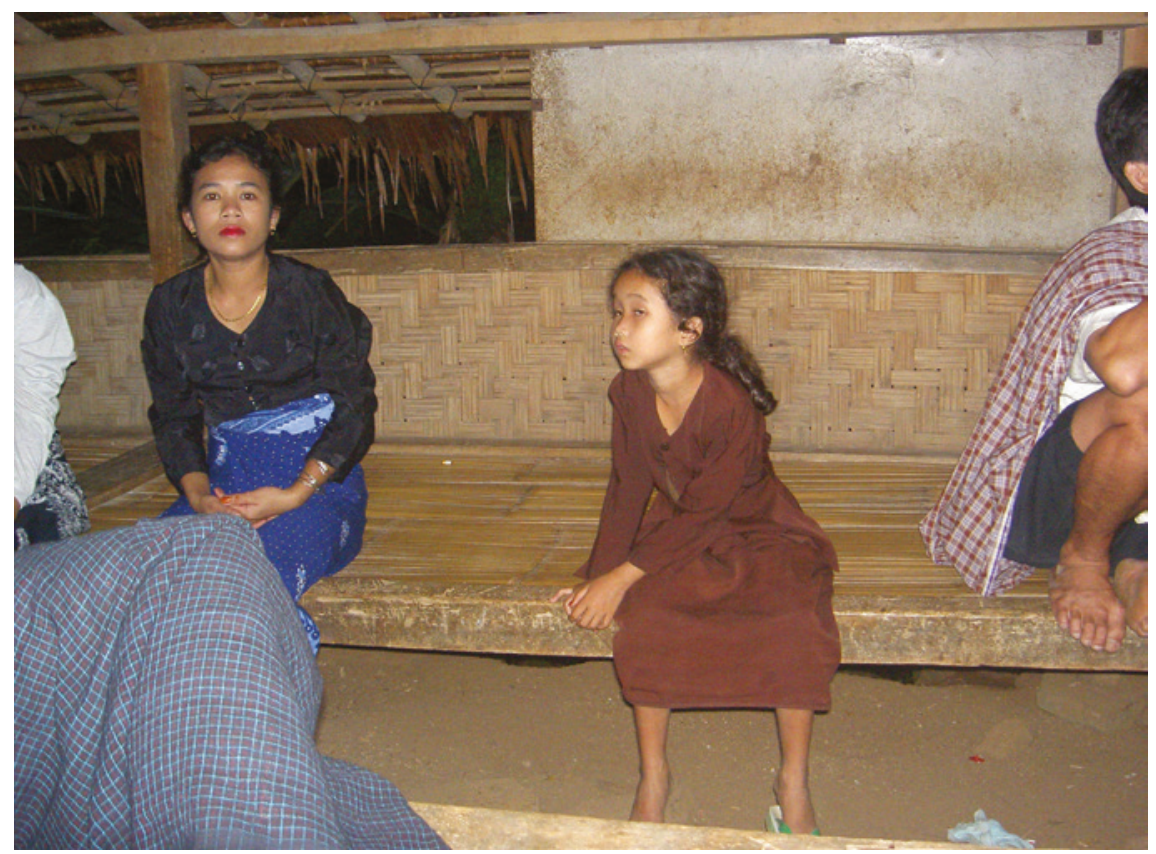

FIGURE 51 Young woman and girl in the audience of the performance by Raidah et al., Kaduketug 1, 26 March 2003 


\subsection{Major Themes in Other Song Texts}

In 1976 I collected six songs sung with angklung accompaniment. As said, these angklung texts in Appendix 4, part A, are less close to the performances than Raidah's texts discussed in Section 7.3 above. However, they show enough interesting features to be briefly discussed. The singer with angklung accompaniment is always a man, and not playing one of the instruments himself. The recordings of singing in 1992 (Part B, Appendix 4) are even less reliable, and I decided to include only part of those text transcriptions here.

\subsubsection{Moral Advice}

Two stanzas of the 1976 song Ngasuh (To take care) give moral advice. The first one says that unmarried boys are already sitting close to the girls, and it means to say that this is improper behaviour. In stanza 3 it says that, if you are in love, you should not show this; you should be able to disguise it. Further advice is given in stanza 2 of 1992-o1 Ceuk Arileu: 'The man who does not think easily ends the marriage - do not take him'. Close to the last one is the text 'A man who does not think does not realize that women may not like him' (D, 2003-13, stanza 12).

Advice is also given in part D of Appendix 4, and recorded in 2003. These susualan were recited without singing and reasonably reliable. Good advice is given in several stanzas:

- 'Although we are distracted, do not forget the one you love' (D, 2003-12, stanza 15)

- 'If you really don't want it, let it not come to a break' (D, 2003-12, stanza 16)

- 'Do not fall in love with your guest(s), when she/he goes home you will miss her/him' (D, 2003-13, stanza 11).

Good advices are also given in the susualan that were given by a person from the Inner Baduy hamlet Cibéo:

- 'Although we do forget, do not forget about love' (D, 2003-15, stanza 4)

- 'But then again, when we go to someone, we must be aware of god' (D, 200315, stanza 10)

The Inner Baduy also have erotic feelings and express these:

- 'Don't smile and [sit] close by, it may be that I want you' (D, 2003-15, stanza 9).

Also for the Inner Baduy a good relation may end:

- 'Yesterday we talked, today we end our marriage' (D, 2003-15, stanza 8).

\subsubsection{Hurt by Outsiders}

In the Cibéo collection (2003-15) there are some interesting susualan that may be seen as expressions of common feelings in the Baduy community: 
- 'This stupidity is your own mistake! Because of stupidity you will be hurt by strangers' (D2003-15, stanza 6).

Baduy very much feel that they should not make mistakes when dealing with people from outside their community. There is a general feeling that they may be misled and exploited by outsiders. Therefore they try to avoid being tricked. They want to stay independent as much as possible, also in their dealings with the Indonesian authorities, as I have pointed out in Chapter 2, especially Sections 2.1, 2.3 and 2.4.

\subsubsection{Dirty Words}

Some of the stanzas with 'dirty words' may be found in the susualan collection from Kaduketug (2003-13):

- 'Grandmother does not want to get up, she is farting incessantly' (stanza 2);

- 'The woman has a bald head, if you get near [you will notice] she stinks from farting (stanza 3);

- 'Nowadays the women fart a lot and wet the bed even more' (stanza 9).

There are only three such examples in my collection, but it is remarkable that they all concern women with undesirable characteristics: farting, having a bald head and wetting the bed. In 1995 I wrote that I heard boys singing 'some dirty phrases' in the early morning after the ceremonial marriage of the goddess of rice to the earth (Van Zanten 1995: 534). These sung words were 'old penis/ scrotum' (kontol péot), definitely referring to the male genitals (A1992-1: 64). Hence Baduy do know dirty words and sometimes use them in susualan and this contradicts what Meijer (189o: 477) wrote.

\subsubsection{References to Music and Dance}

I also looked at references to music and dance in the susualan of my collection. There are a few interesting passages, like:

- 'Why do the gamelan musicians not shout encouragements? Because they have not been given a hot drink (tea)' (2003-12, stanza 13).

The gamelan musicians are supposed to shout encouragements (senggak) as comments on what the puppeteer (dalang) or the female vocalist (sindén) has said or sung. It is generally felt as enhancing the good atmosphere of the performance. This is similar to what I described in Section 7.3 above for the song Kapergok in which Raidah sang 'Hey, elder brother, what are you doing?' and in response the village secretary shouted that he was drinking coffee. When a group performs the host and hostess are responsible for supplying food and drinks for them. If the gamelan musicians do not get their drinks, they will not get into the right mood and the performance will be less cheerful and animated (ramé). 
Stanza 2 of 1992-01 and stanza 12 of 2003-13 both start with the line 'the kacapi is ornamented with woodcarvings'. This is the first line of the 'rind' (cangkang) and the words may only be taken because of the wanted sound association. However, this sentence is remarkable in the sense that the Baduy zithers made in Kanékés do not have any woodcarvings and are made from plain white lamé wood. Therefore this line probably refers to a zither made outside Kanékés and the susualan may have been taken from outside the Baduy community. The only 'decoration' of kacapi pantun may be a white cross (tumbal) put on the sound board with some kind of chalk, like the one on Yanci's kacapi in Van Zanten (2016a: 417) and the violin in Figure 54 below. This is used to protect the player from bad outside influences (see also Van Zanten 1989: 94-95).

In stanza's 2 and 3 of 1992-7 (Néng Gaya), the vocalist (Raidah) mentions that the drummer (tukang kendang) has a style, or manner (gaya) of drumming, the kacapi player has a style of playing, and the rendo player has a style of playing. Each time she adds that she also has a style and her style is the same as the one of the drummer, the zither player and the violin player. They all have the same style and they are very good! In a more general sense this text seems to emphasize that all people are equal.

Another susualan raises the 'singing contest' of boys when trying to find a wife (ngaroronda): 'Do not be ashamed to be jealous when we sing in turns' (1976-4, stanza 4). On these occasions the boys may accompany their own singing on a kacapi. Music is frequently used for courting and it is especially the softer instruments, like the karinding Jew's harp and the kacapi, that are used, sometimes for accompanying the singing. It is said that the karinding is still frequently used by Inner Baduy women when courting. Apparently some sounds of the karinding may allude to word sounds in a susualan (Ukang Sukarna, A2003-2: 13).

\subsubsection{False Instruments and Social Order}

Two of the Baduy susualan in Appendix 4 speak about the suling that is out of tune (silung, plural sarilung) and this is taken as a metaphor for the person, who is 'confused' (2003-12, stanza 7 and 2003-14, stanza 2). This text also shows repetition of the vowel pattern in reverse order: $u-i$ and $i-u$ in the second line (that is, chiastic assonance; see Eringa 1949: 106; Van Zanten 1989: 66). I have discussed this susualan text, also used in Cianjuran singing of the Priangan, and pointed out that a badly tuned instrument may also be used as a metaphor for a social situation that is out of order and unbalanced (Van Zanten 1989: 105, 194-195; 1994: 87-9o; 1997: 46). In my collection these two susualan were just quoted and not performed, however texts about 'false gongs' are found in the 
Baduy pantun stories as shown in Section 6.5 above and specifically in Table 13 and Music Transcription Tr 6.

The next chapter is about music produced by wind and string instruments. This includes flutes played by human beings, but also instruments that make sound produced by the wind. The string instruments include different types of zithers and violins. Most of these instruments can be played on their own, but also in small groups, like the Raidah ensemble discussed in Section 7.3 above. 